\title{
Lumen
}

Selected Proceedings from the Canadian Society for Eighteenth-Century Studies

\section{Horatio the Hero: The Depiction of Horatio Nelson in Contemporary Historical Fiction}

\section{Martha F. Bowden}

Volume 29, 2010

URI : https://id.erudit.org/iderudit/1012031ar

DOI : https://doi.org/10.7202/1012031ar

Aller au sommaire du numéro

Éditeur(s)

Canadian Society for Eighteenth-Century Studies / Société canadienne d'étude du dix-huitième siècle

ISSN

1209-3696 (imprimé)

1927-8284 (numérique)

Découvrir la revue

Citer cet article

Bowden, M. F. (2010). Horatio the Hero: The Depiction of Horatio Nelson in

Contemporary Historical Fiction. Lumen, 29, 129-142.

https://doi.org/10.7202/1012031ar

Copyright (c) Canadian Society for Eighteenth-Century Studies / Sociéte canadienne d'étude du dix-huitième siècle, 2010
Ce document est protégé par la loi sur le droit d'auteur. L'utilisation des services d'Érudit (y compris la reproduction) est assujettie à sa politique d'utilisation que vous pouvez consulter en ligne.

https://apropos.erudit.org/fr/usagers/politique-dutilisation/ 


\section{Horatio the Hero: The Depiction of Horatio Nelson in Contemporary Historical Fiction}

Horatio, Lord Nelson, continues to be one of the great heroes of England for his combination of bravery, charisma, and mighty conquest. Two events in his life, however, rendered him a flawed hero: his involvement in the tribunal in the Bay of Naples in 1799, after the short-lived republic of Naples, where he and Sir William Hamilton were widely considered to have treated the Neapolitans, especially Commodore Caracciola, to summary and incomplete justice on behalf of an utterly corrupt regime; and his flagrant affair with the married Emma Hamilton, wife of Sir William, and his treatment of his wife. In his own time, these events were less important to most people than his victories at the Battle of the Nile and Trafalgar. Robert Southey wrote his 1813 biography of Nelson as a guidebook for young men wishing to follow in Nelson's illustrious footsteps:

Many Lives of Nelson have been written; one is yet wanting, clear and concise enough to become a manual for the young sailor, which he may carry about with him till he has treasured it up for example in his memory and in his heart. In attempting such a work I shall write the eulogy of our great national hero, for the best eulogy of NELSON is the faithful history of his actions, and the best history must be that which shall relate them most perspicuously. ${ }^{1}$

While Southey subsequently refers to the Bay of Naples affair as the sole blot on Nelson's record, he recounts all the myth-creating stories to compose a portrait of a man born to be a hero, and insists, against all the evidence, that the love affair with Emma Hamilton was platonic.

1 Robert Southey, The Life of Horatio Lord Nelson [1813] Amazon Kindle edition. 
Admirers found many ways to honor him. In 1802, a young Irishman named Patrick Prunty or Brunty changed his name to Bronte on entering St. John's College, Cambridge; by 1811, he had added the umlaut over the "e." ${ }^{2}$ His daughters made this more refined version of the family name famous, but it originated in the dukedom granted to Nelson by Ferdinand, King of Naples, in 1799. Streets, rivers, and cities across what used to be the British Empire still reflect Nelson's various names and titles (Horatio, Viscount Nelson of Burnham Thorpe, Duke of Brontë). In Brampton, Ontario, just outside the city of Toronto, the streets in the nineteenth-century core of the city include Queen, George, Clarence, Peel, Wellington, and Nelson. Toronto has Burnhamthorpe Road; and as one drives towards Burlington, it is possible to take the Trafalgar Road to Trafalgar and Bronte before the route passes Bronte Creek Park. Not far away is Palermo, named for the second capital of the Kingdom of the Two Sicilies, to which Nelson evacuated the royal family in the wake of the Neapolitan Revolution.

There is evidence, however, that some of his contemporaries were not as blindly enthusiastic. Jocelyn Harris, in "Domestic Virtues and National Importance': Nelson, Captain Wentworth, and the English Napoleonic War Hero," argues that Jane Austen develops the character of Wentworth in Persuasion from several heroic figures, including the Nelson of Southey's biography. In the process, she "tests various models...and finds them wanting." ${ }^{3}$ Nelson fails in several areas. Austen adjusts his appearance from the battered and fragile figure that was Nelson by the time he became the Hero of the Nile (blind in one eye, minus an arm, pale and slight) to a much more vigorous frame; Wentworth looks every inch the hero. She incorporates many of Nelson's best characteristics, notably his kindness to his subalterns. Nonetheless, Nelson's behavior, like his appearance, is not suitable for her purposes, Harris notes; Austen sets the novel in Bath, where, while Nelson was considered a hero, his treatment of his father and his wife, both of whom lived there, were equally well-known. ${ }^{4}$ Despite her affection for the navy in which her brothers served, Austen could not completely accept its greatest contemporary figure as a model: "the adulterous

2 Oxford Dictionary of National Biography, s.v. "Brontë, Patrick (1777-1861)" (by T.J. Winnifrith), http://www.oxforddnb.com (accessed July 25, 2008).

3 Jocelyn Harris, "'Domestic Virtues and National Importance': Lord Nelson, Captain Wentworth, and the English Napoleonic War Hero," Eighteenth-Century Fiction 19 (2006-7): 202.

4 Ibid., 189. 
admiral was no exemplar for the 'domestic virtues' lauded in the last sentence of her novel. ${ }^{\prime \prime}$

Nelson's legend is built on signature elements: his personal modesty; his striking achievements, such as capturing one ship from the deck of another, referred to by Patrick $O^{\prime}$ Brian in the introduction to his novel, Master and Commander; his gift for exactly the right expression ("England expects every man to do his duty," the signal to the fleet at the commencement of the Battle of Trafalgar). Like James Wolfe, he paid the ultimate price and his death was accorded a similar, Pietà-like depiction in a painting by Benjamin West. But the unease his contemporaries felt at the discrepancy between his exploits in the navy and his behaviour both in the Bay of Naples and in his private life, while it tarnished but did not erase his heroism in his own day, continues in our own. No one doubts that his exploits are remarkable, but his private character is increasingly emphasized and seen as problematic. In contemporary historical fiction, the effect of the emphasis on the private shortcomings is to undermine his heroic stature. This essay examines the strategies of a number of contemporary novels that concern themselves with the figure of Nelson, either as a central character or as a peripheral figure.

Nelson's absence from a critical twentieth-century novel paradoxically underlines his importance as an English hero. When Winston Smith, the anti-hero of George Orwell's anti-Utopia, Nineteen EightyFour, goes to Victory Square for an assignation with a girl he has met at work, he spends the time before she arrives wandering about, looking at the architecture, and taking "a sort of pale-colored pleasure," the only kind available in this grey domain, in identifying St. Martin's Church, "whose bells, when it had bells, had chimed 'You owe me three farthings.'" The church has been converted into a wing of the enormous civil bureaucracy, a propaganda museum whose exhibits feature weapons of war and scenes of atrocities by the enemy. He sees a man on a horse, "which was supposed to represent Oliver Cromwell," and, on a great fluted column, the head of Big Brother, looking "southward toward the skies where he had vanquished the Eurasian airplanes." ${ }^{16}$ In the reversed world of Oceania, in which England is not randomly upturned but mirror-imaged, the man who works for the Ministry of

5 Ibid., 181.

6 George Orwell, Nineteen Eighty-four, Foreward Thomas Pynchon, Afterword Erich Fromm. Plume/Harcourt Brace Book. (New York: Penguin Group, 2003), 116, 101102. 
Truth, where he spends his time rewriting history, and where papers sent down the memory hole are blotted out of existence, is unaware of the extent to which his country's history has been erased and upended. He has no way of knowing that he is standing in Trafalgar Square, because the dicta of the new regime have required particularly rigorous relabeling. Charles I, defeated by Oliver Cromwell, has had his identity replaced with his conqueror's, although Cromwell's victory was notably short-lived. Even more significantly, however, the hero of Trafalgar, who is the key emblem of the time when Britannia ruled the waves, and who gained many of his successes by ignoring authority, has been eliminated altogether, and a new icon, the emblem of the repressive government that has blurred entirely the distinction between slavery and freedom, has replaced him. In a world in which irony is a luxury that no one can afford, it would be pointless to tell Smith that the ship on which Nelson lost his life, in the midst of his greatest naval engagement, was called the Victory.

In the twentieth century, novelists have drawn on the figure of the martyred hero of Trafalgar for images of ultimate heroism. William Rivers, one of the central characters in Pat Barker's Regeneration trilogy, and historically a distinguished psychologist who treated soldiers sent home from the front in World War I, was named for his ancestor, "who, as a young midshipman, had shot the man who shot Lord Nelson." The Rivers family has gloried in the connection ever since, even changing the Nelsonian mythology: "And the great man, dying, had not indulged in any effete nonsense about kissing Hardy, nor had he entrusted Lady Hamilton to the conscience of a grateful nation. No, his last words had been, 'Look after Will Rivers for me.'" Young William, weeping in response to his first haircut, is held up to the treasured family icon, a painting of his namesake stoically having a leg amputated without anesthetic, as a model for the correct behavior. Later, seeing the weight of ancestry on a native medicine man he is observing in the South Seas, Rivers repeats the phrase that sums up the burden of his own inheritance: "It was worse...than being the great-nephew of the man who shot the man who shot Lord Nelson."

Even more pervasive is Nelson's influence on Patrick O'Brian's Aubrey/Maturin series, not surprisingly because it is set in the British Navy in the Napoleonic period. The second sentence of the Author's Note at the beginning of Master and Commander uses one of Nelson's most famous exploits to support the contention that in this period 
"improbable reality outruns fiction...Nelson leaping from his battered seventy-four-gun Captain through the quarter-gallery window of the eighty-eight gun San Nicolas, taking her, and hurrying on...to board the towering San Josef..." Jack Aubrey establishes some of his flair by his associations with Nelson; the description of him on the first page of Master and Commander includes the detail that he wears "the silver medal of the Nile in his buttonhole. ${ }^{\prime 8} \mathrm{He}$ regales dinner guests with tales of the two dinners he ate in the great man's company; at one of them, Jack tells his audience without irony or self-consciousness, Nelson asked him to pass the salt. The description of Nelson that $\mathrm{O}^{\prime}$ Brian places in Jack's mouth encapsulates the entire Nelson mythos, reflecting the reverence with which he was viewed by his men and the peculiar combination of gentleness and power that he commanded: "He is very slight - frail - I could pick him up (I mean no disrespect) with one hand. But you know he is a very great man directly." Jack quotes one of Nelson's trademark pithy comments ("Never mind maneuvers - always go at 'em") as well as one of the over-the-top declarations of patriotism for which he was equally well known: "he was telling us all how someone had offered him a boat-cloak on a cold night and he had said no, he was quite warm - his zeal for his King and country kept him warm." Both the warmth of expression - sentimental coming from anyone else as Jack realizes: "It sounds absurd, as I tell it, does it not?" - and Nelson's lack of hesitation in repeating it are typical of the man. ${ }^{9}$ Jack has other connections - he was at the Battle of Saint Vincent, which he celebrates every year, and he escorted the Généreux to shore when the British navy under Nelson captured it at Mahon. He wears his hair "loose and long," as a tribute to his hero. ${ }^{10}$

But more striking than the references to Nelson is the character of Jack Aubrey himself, whose charisma, rapport with his men, aversion to sadistic discipline, and difficulties with authority all mark him as being cast in the Nelson mold: "He walked with the utmost confidence, as if he had just won the battle of the Nile in person.."11 Stephen Maturin, that observer of men, as reflective as Jack is active, sees in his

8 Patrick O'Brian, Master and Commander, The Aubrey/Maturin Series (New York: W.W. Norton \& Co., 1990), 13.

9 Ibid., 130-31.

10 Patrick O'Brian, Post Captain, The Aubrey/Maturin Series (New York: W.W. Norton \& Co., 1990), 38, 250; Master and Commander, 173.

11 O'Brian, Master and Commander, 31. 
friend's admiring description of his hero a portrait of Jack himself: "Ld. Nelson, by Jack Aubrey's account, is as direct and unaffected and amiable a man as could be wished. So, indeed, in most ways, is JA himself, though a certain careless arrogance of power appears at times. ${ }^{12}$ Other characters note this similarity; Diana Villiers observes to Babbington, one of Jack's admiring midshipmen, that "Captain Aubrey must be very like Lord Nelson," and Babbington agrees enthusiastically. ${ }^{13}$ Even his troubles with the admiral Lord Keith echo Nelson's own career; Keith is known as the only commander whom Nelson ever disobeyed. Jack's exploit in capturing the Spanish xebec, the Cacafuego, is very like that of Captain Cochrane, one of Nelson's protégés. According to Edgar Vincent, one of Nelson's modern biographers, Nelson met Cochrane in Palermo; Cochrane notes in his autobiography the encouragement he received from Nelson, and quotes the tag that Jack also remembers so fondly: "Never mind the manoeuvres, always go at them." Vincent describes the connection between the two as "Like had been speaking to like, for as a dashing, aggressive, humane frigate captain, Cochrane would prove to be at least Nelson's equal." ${ }^{\prime 14}$ By extension, we may include Aubrey here too, although there are distinct differences as well. Like Austen, O'Brian changes the physical appearance of his avatar of Nelson; Jack is far from frail - ruddily healthy, he inclines to stoutness rather than an ethereally slender frame.

David Donachie's Nelson and Emma trilogy, unlike the O'Brian opus, may be safely avoided without any reader missing an engaging or inspiring literary experience. My own faltering patience with its clichés, redundancies, and other infelicities of style was completely eroded when Donachie failed the litmus test for historical fiction, that it should get the small details correct. Historical fiction has license to speculate, and there are many unknown details in the romance of Emma Hamilton and Nelson where the novelist may do so, but under

12 Ibid., 203.

13 O'Brian, Post Captain, 46.

14 Edgar Vincent, Nelson: Love and Fame (New Haven and London: Yale University Press, 2003), 356-57. Dean King with John B. Hattendorf, Harbors and High Seas: An Atlas and Geographical Guide to the Complete Aubrey Maturin Novels of Patrick O'Brian, $3^{\text {rd }}$ Edition (New York: Henry Holt and Co., 2000), 49-50, notes that $\mathrm{O}^{\prime}$ Brian admits "he modeled many of the events of the novel...on Lord Cochrane," including the taking of the Cacafuego, but does not connect the "manoeuvres" tag with Cochrane. The line is quoted differently in Vincent's and O'Brian's texts. 
no circumstances is it safe to say that Homer wrote The Aeneid. ${ }^{15}$ The work is useful as a treatise on the trademark events of Nelson's life in his pursuit of hero status, however, for all writers agree that at the age of eighteen Nelson had decided that he would become, not a Lord of the Admiralty, but a hero. Thus Donachie recounts his arrival at his first position as a midshipman (a tale much told but which Vincent disputes $^{16}$ ), his wounds, his rapport with his men, his message to his fleet before Trafalgar, and his miraculous feats of navigation. Like the Rivers family, however, Donachie feels a need to rewrite the troublesome death scene in his own way - the ship's surgeon, recording the hero's last hours, changes "Kiss me, Emma," to what has come down in history. ${ }^{17}$

Even the most admiring fiction and the most adulatory biography stumbles over the Hamilton affair and the tribunal in the Bay of Naples. Southey, despite his willingness to dismiss the relationship with Emma Hamilton as a platonic infatuation, can find nothing to justify the actions of the tribunal, and explicitly links it with Emma's deleterious influence. He describes Nelson's repudiation of Ruffo's treaty with the revolutionaries as, "A deplorable transaction! a stain upon the memory of Nelson and the honour of England! To palliate it would be in vain; to justify it would be wicked. ${ }^{\prime 18}$ Of the hasty execution of Caracciolo, the Neapolitan Commodore, he is even more condemnatory, implicitly charging Nelson with both self-deception and infidelity: "Doubtless, the British Admiral seemed to himself to be acting under a rigid sense of justice; but to all other persons it was obvious that he was influenced by an infatuated attachment - a baneful passion, which destroyed his domestic happiness, and now, in a second instance, stained ineffaceably his public image." ${ }^{19}$

15 '"Aeneid,' said Nelson, stepping forward to give the agreed password, appropriate, since it was the title of Homer's tale, which was partly about the flight of royal survivors from the sack of Troy" (David Donachie, Tested by Fate, The Nelson and Emma Trilogy 2 [Ithaca, N.Y.: McBooks Press, 2000], 370).

16 Vincent believes the story emerged from Nelson's own strong impulse to self-dramatize, although he notes that Nelson's father had been careless about sending him off. (Vincent, Nelson: Love \& Fame, 17).

17 David Donachie, Breaking the Line, The Nelson and Emma trilogy 3 (Ithaca, N.Y.: McBooks Press, 2004), 359.

18 Southey, Life of Horatio, Lord Nelson.

19 Ibid. 
Donachie uses Emma Hamilton as an excuse to provide the explicit sexual details that romance fiction apparently now requires, and that Nelson's life would be distinctly lacking otherwise. The sordid public affair in the Bay of Naples, however, unlike the private one, draws from him an awkward form of apologetics. His Nelson, aware of the persuasive power of Caracciolo's argument, and having the power to refute the sentence, hesitates because he thinks the Commodore is "arrogant." He takes counsel from his two most trusted advisors, Sir William and Lady Hamilton; Emma is presented as conflicted, but Sir William, the seasoned diplomat, announces that the execution must go forward: "Clemency would only be construed as weakness." Thus the real villain is the political Hamilton, not the heroic Nelson or the tender-hearted Emma, and Nelson signs the death warrant because he feels he has no choice: "though he might be the King's representative, he was not empowered to interfere in an internal matter." When Caracciolo is led to the scaffold, Nelson cannot meet his eyes. None of this explanation squares with the historical image of the independent Nelson whose attitude towards commands he disliked was to ignore them, and who never flinched from his enemies, nor apparently felt compelled to question his own actions. As vindication, it is hardly successful. ${ }^{20}$

O'Brian deals with Nelson's lapse by deflecting the criticism to a minor character who is speaking to Maturin, so that Jack's hero worship can continue unabated. The critique is further removed from Nelson himself by laying the blame on Emma Hamilton in a misogynistic tone that is typical of the sailors O'Brian portrays. Maturin has been attempting to reassure Macdonald, who has had an arm amputated, and whose stump is healing well: "In a few weeks' time you will rival Nelson, spring one-handed from ship to ship - happier than the Admiral in that you have your sword-arm still."' The marine is at first reassured, but is not entirely pleased by the comparison. He claims that "he is no hero of mine. Caracciolo sticks in my gullet. And then there is his example...Whoremongering - lingering in port - hanging officers who surrender on terms. A pretty example!...I hate women. They are entirely destructive. ${ }^{\prime 21}$ His words reveal betrayal, disgust, and a need to find some other villain. Like Southey, he finds it necessary to persuade himself that the love affair is at the root of the matter, although he does not believe it is platonic.

20 Donachie, Breaking the Line, 48-49.

21 O'Brian, Post Captain, 348. 
The conflict between the hero and the villain is most brilliantly portrayed in Barry Unsworth's Losing Nelson, although it is not historical fiction but a novel about an obsession with history. Charles Cleasby, the protagonist, who is laboring to write a biography of Nelson, gradually loses what little grasp he has on his sanity in attempting to reconcile his devotion to the man with his idol's shortcomings. Cleasby has a theory of historical parallelism in which people in the present live their lives as doubles of historic figures from the past. He eventually comes to believe that he is Nelson's double: "I did not then...see myself as an angel like him, a creature of radiant violence. That came later. At the time I thought of myself merely as a repository of his essence, a sort of memorial urn. But I knew that the same forces had moulded us both - thoughts of his childhood led me always back into the labyrinth of my own."22 His life is calibrated to Nelson's career; his ritual recreations of Nelson's battles, played out in real time on their anniversaries every year, make Toby Shandy's bowling-green fortifications look like a casual weekend hobby. Thus his desperate attempt to write a life of Nelson is an even more desperate sortie at explaining his own. Eventually the two identities merge: "In spite of all appearances to the contrary, in spite of my obscure life, I knew that he and I were at one, we were like diamond and carbon. ${ }^{\prime 23} \mathrm{He}$ links his destiny even more closely to his hero by determining that his own role, like Nelson's decision to be a hero, should be a life pursuit that would make his memory immortal: "My name would be joined with his for as long as his deeds were remembered. Charles Cleasby, the vindicator of Horatio Nelson." ${ }^{24}$

$\mathrm{He}$ is able to rationalize the affair with Emma Hamilton and the treatment of his wife, "the strange discrepancy between his private and his public life," in an act of deliberate self-deception that resembles Southey's resolution of the question of adultery. Most sensible people would consider Nelson's attempt to have wife and mistress together in a kind of harmonious community as delusional at best and brutally selfish at worst. Cleasby, however, desperately attempts to explain it as a kind of heroic self-confidence: "He expected the fear and antagonism of the women to melt in the warm breath of his enterprise, as the odds had melted at Cape St. Vincent and would again at Trafalgar. Sure mark of the hero, this believing so completely in the transforming power of

23 Ibid., 104.

24 Ibid., 111. 
his desire." ${ }^{25}$ The paralyzing problem is "that time of travesty in Naples and Palermo," ${ }^{26}$ and the tribunal at the Bay of Naples, "the heart of the problem that had held up my book and exhausted my mind for more than two months...I was beginning to feel the usual nausea of defeat, that slackening and slipping away of the mind which seemed like a foretaste of death. ${ }^{\prime 27}$ The visit to Naples that is supposed to resolve all the doubts, to retrieve from the "great heap of argument" the "bright fragment that would clear his name" ${ }^{\prime 28}$ subverts the usual biographical assumption that retracing the subject's footsteps leads to an illumination of the life. Instead he discovers that there is almost no record at all of the Hamiltons having been there, and no desire on the part of the Neapolitans to revisit that part of their history.

The first reference to Nelson in Susan Sontag's The Volcano Lover rises through the consciousness of Maria Carolina, Queen Consort of Naples, for whom he is a peripheral figure in her overwhelming concern for the welfare of her sister Marie Antoinette. In this initial appearance, he is referred to by his own name: "The British naval commander who had anchored in the bay for five days, Captain Nelson, had won a great victory over the French, and been most encouraging about British resolve; but the Queen placed little trust in military solutions. ${ }^{29}$ Thereafter he is known chiefly as "the hero," a term whose irony increases with his fame. To the Cavaliere and his wife he is a man on the verge of being famous: "When they first saw him, he had not fought any important battles. But he had the look, the hungry look that evinces the power to concentrate utterly on something, of one destined to go far...A star is always a star, even before the right vehicle has been found, and even after, when the good parts are no longer available. And the thirty-fiveyear-old captain was undoubtedly a star - like the Cavaliere's wife." ${ }^{\prime 30}$ The Cavaliere's recognition that the young man "will be the bravest hero England has ever produced" is overshadowed by its conflation with stardom, with staging and self-representation, and the equivalency with the Cavaliere's wife sounds a note of warning.

26 Ibid., 92.

27 Ibid., 117.

28 Ibid., 111.

29 Susan Sontag, The Volcano Lover: A Romance (New York: Picador/Farrar, Straus and Giroux, 1992), 182.

30 Ibid., 188. 
He comes back to Naples five years later, after the Battle of the Nile, after "History promoted him," and "War confiscated parts of his body," a fully-fledged hero who "vaulted into their lives." ${ }^{11}$ Yet the ambivalence continues, constructed by layers of references that are only slightly separated by more transparent text. Thus the conventional attribution of fame to the spirit of the time, "It was a time for concentrated men of preposterous ambition and small stature who needed no more than four hours of sleep a night," is first supported by a deceptively lyrical description of "the rocking sea and the lurching ship," giving chase and winning battles, the succession of ships and promotions, and is then dislocated by an unhappy comparison with the terror of the people of Naples, "the small concentrated man who had taken over a fractured revolution and transposed its energies into a seemingly invincible campaign for the French conquest of Europe. ${ }^{32}$ The connection with Napoleon is as obvious as the ambiguity: is it heroic to want to be a hero? Or do heroes simply emerge, with becoming modesty and reluctance, from the eruption of extraordinary events? For Southey, Donachie, and Jack Aubrey, it is perfectly reasonable, indeed exemplary, to wish to be a hero. Donachie's failure is most pointed here; he begins well, with Nelson's visit with his mother to see Benjamin West's famous history painting, The Death of Wolfe. But when towards the end he asserts Nelson's diminished desire for heroism (a development that no other depiction of the hero mentions) he misses the central irony - that Nelson too will have his death recorded by West, in a similar mode, and one that is in fact closer to the historical conditions of his death than Wolfe's. Sontag, however, is less generous, and more insistent, more troubled about the impulses behind the drive: "He intended to be a hero. He wanted to deserve praise, to be decorated, remembered, to figure in history books. He saw himself in history paintings, as a portrait bust, as a statue on a pedestal, or even atop a high column in a public square. ${ }^{\prime \prime 3}$ Sontag's Nelson sees heroic identity as far more a matter of fame and praise in the public forum than of actions. An unrecorded hero is apparently no hero at all. She forces us to consider that in granting him the adulation he desires so strongly history is not rewarding his worthy ambition but is complicit in his vanity.

31 Ibid., 189, 191.

32 Ibid., 189.

33 Ibid., 193 
The love affair between the hero and the Cavaliere's wife is not particularly problematic to Sontag, who in fact describes it and the triangle with a great deal of sympathy. Her Emma Hamilton, although undoubtedly a self-promoter, has a generosity of spirit that allows her to inspire passion in two men who had rarely felt such an emotion. About the Bay of Naples tribunal, however, she is merciless, and less inclined to apologetics than any other of these writers. She refuses to blame the Cavaliere, who is as diplomatic as in Donachie's portrayal, but here counsels prudence, suggesting that "it might be well to follow custom and defer the execution for another twenty-four hours"; the hero goes ahead regardless. She presents the rationalization for his execution of Caracciolo in an indirect discourse from which the authorial voice is as far distanced as irony can set it: "By the rules of war the hero had no right to abrogate Ruffo's treaty with the rebels, no right to abduct and execute the Bourbon monarchs' senior naval officer or even to receive him on board an English ship as a prisoner; but this was not war. This was the administration of punishment." Her acidic description of the procedure against the rest of the revolutionaries suggests her own opinion of the proceedings: "After lynching comes judicial murder, which involves a good deal of paperwork. ${ }^{134}$ Her summation of the event speaks overtly, challenging any attempt to explain or vindicate:

If they were a mob, one would have said that the beast had had its fill of blood. Since they were individuals, claiming to be acting for the public good - My principle is to restore peace and happiness to mankind, wrote the hero - one says that they did not know what they were doing. Or that they were dupes. Or that they must have felt guilty after all.

Eternal shame on the hero! ${ }^{35}$

Mrs. Cadogan, the Cavaliere's mother-in-law, accuses Nelson of loving glory more than her daughter: "Why go about the boat in his admiral's frock coat and his stars so a French sharpshooter could find him easy and kill him, if he wanted to stay alive to come back to her...Women may be vain, but when a man is vain it is beyond believing, for a man is willing to die for his vanity." ${ }^{36}$ The last voice is Eleanora de Fonseca Pimental's, whose execution is announced immediately before the 
declaration of eternal shame. She expresses her contempt in a more thorough erasure than the forces of Big Brother; rather than convert the identity of the heroic figure, she dismisses him entirely, as being beneath her notice: "I will not deign to speak of my hatred and contempt for the warrior, champion of British imperial power and savior of the Bourbon monarchy, who killed my friends." ${ }^{37}$

In a sad and sane moment early in Losing Nelson, Cleasby has a melancholy revelation while reflecting on extrapolating truth from legend in the life of Nelson: "Horatio Nelson is the English hero; he has no rival. No threat of rivals in the future, either - this country will never produce heroes again. ${ }^{\prime \prime 38}$ But it may well be that we are culturally unable to accept the concept of the hero, without some tincture of reluctance or irony, some need to remind ourselves that he is "only human." Whether by insisting on bringing forward what his early apologists wished to hide, as in Donachie's use of Emma Hamilton to add a sexual charge to a largely emotionally constrained life, or O'Brian's careful placement of criticism, or Sontag's repeatedly drawing attention to the disjunction between Nelson's behavior and appearance on one hand and his heroic reputation on the other, so that the word "hero" becomes indelibly ironic, none of these texts holds the transparently uncritical tribute so evident in Southey.

Nor does modern biography allow hagiography. Vincent presents his subject in carefully measured terms, describing his charisma while stressing the uncertainties of the visual record. But he also writes of Nelson's addiction to attention and his equally great "thirst for love." As the title of the book suggests, these two attributes are the central facts of his character. He was abnormally aggressive and addicted to battle, but capable of genuine kindness; he was possessed of much common sense, but not always in touch with reality. ${ }^{39}$ Vincent's discussion of the tribunal is also balanced. After carefully rehearsing the details of the case, and stressing the uncertainty of the evidence, he asserts his doubt that Sir William Hamilton was particularly influential, and makes a persuasive argument for the true source of unease about the incident. It is not so much the ruthlessness with which the rebels were treated - he notes that 4 per cent of the rebels were executed, ${ }^{40}$ although that figure

37 Ibid., 418.

38 Unsworth, Losing Nelson, 62.

39 Vincent, Nelson: Love E Fame, 1-3.

40 Ibid., 332. 
would probably not have mollified Sontag - nor that Nelson carried out Caracciolo's execution with more expedition than was customary. Instead, he declares that the blot on Nelson's reputation came about because his actions served to restore a kingdom that was known to be "rotten to the core": "Occasionally Nelson gives real cause for doubt about his grip on reality, or his honesty." ${ }^{\prime 1}$ Given the necessary differences in tone and evidentiary methodology between biography and fiction, this judgment is not significantly different from Sontag's: "He did not see himself as gullible and vain," declares the narrator, where the clear subtext is that he is certainly both, and lacking in self-awareness to boot.

Nelson's status as a hero is not in dispute, in the uncritical sense that he himself understood the term; that he and his greatest battle must be erased from Victory Square in Nineteen Eighty-Four, to be replaced by an image of the most powerful icon in the government, is indicative of his importance. But what the other novels highlight, whether deliberately or inadvertently, is contemporary difficulty with heroism itself. Sontag's increasingly ironic use of the word "hero" suggests that we are no longer able to treat the private vices and shortcomings of leaders as irrelevant to their public reputation. Unlike Southey, the twentieth-century writers about whom I have written all concentrate on his humanity, and under that scrutiny the possibilities for traditional heroism evaporate. The tribunal at the Bay of Naples and the affair with Emma Hamilton can no longer be avoided, brushed aside, or explained away. Like Jane Austen, we expect the domestic life to be as beyond reproach as the evidence of bravery. On the other hand, the emphasis on his humanity has the corollary effect of making his weaknesses understandable. When his frail physical appearance ceases to be part of his legendary superhuman nature - the ethereal and murderous angel of light that Charles Cleasby clings to - and when he is seen for what he is, with all his shortcomings, it becomes possible to reconcile his great accomplishments with the foibles of his personal life, without diminishing the accomplishments or finding it necessary to turn a blind or apologetic eye to the foibles. That may be the modern form of heroism.

MARTHA F. BOWDEN

Kennesaw State University

41 Ibid., 334-35.

42 Sontag, The Volcano Lover, 193. 